\title{
Senior Citizens as an Underresearched Age Group of Audiovisual Translation Users
}

\author{
Sonia Szkriba \\ University of Warsaw, Poland \\ s.szkriba@uw.edu.pl
}

\begin{abstract}
In recent years, approaches to audiovisual translation and media accessibility services have shifted from serving one group of viewers only towards a more universal design that takes into account a wider range of users. In line with that approach, some scholars point out, for example, that subtitling for the deaf and hard of hearing (SDH) or accessibility applications created with the blind and partially-sighted in mind could prove beneficial to senior citizens. This group of viewers is likely to experience age-related sensori-motor and cognitive decline, which may significantly influence their film-watching experience as well as their preference for an AVT method. As populations in many countries are aging, senior citizens might be considered an important part of potential cinema clientele. Unfortunately, since studies in AVT have concentrated on younger audiences, little is known about senior citizens' specific preferences concerning audiovisual translation. The objective of this article is to briefly characterise senior citizens as recipients of audiovisual translation and discuss the possibilities for future studies on the subject.
\end{abstract}

Keywords: senior citizens, audiovisual translation, media accessibility

\section{Streszczenie}

Osoby starsze jako niezbadana grupa odbiorców przekładu audiowizualnego

W ostatnich latach zauważalna jest zmiana podejścia do usług oferowanych $w$ ramach przekładu audiowizualnego i dostepności mediów. Zamiast skupiać się na konkretnej grupie widzów, widoczne jest dażenie do bardziej uniwersalnych rozwiazań, które brałyby pod uwage odbiorców o różnej charakterystyce. Zgodnie z tym podejściem niektórzy badacze sugeruja na przyktad, że napisy dla niestyszących (SDH) czy aplikacje dostępnościowe stworzone z myśla o osobach niewidomych mogłyby być użyteczne także dla osób starszych. U tej grupy widzów moga występować typowe dla starzenia zmiany w narzadach zmystu czy obnizenie sprawności poznawczej, co może mieć istotny wplyw na proces oglądania filmów oraz preferowana metode thumaczenia. Biorac pod uwage starzenie się populacji wielu krajów, można założyć, że osoby starsze stanowia ważna część grupy potencjalnych klientów kin. Niestety niewiele wiadomo natemat konkretnych potrzeb $i$ preferencji osób starszych zwiazanych $z$ przekładem audiowizualnym, ponieważ dotychczasowe badania skupiaty się na młodszych widzach. Celem 
tego artykułu jest krótkie scharakteryzowanie osób starszych jako odbiorców przekładu audiowizualnego oraz omówienie tematów, jakie moga podjać przyszłe badania nad ta grupa widzów.

Stowa kluczowe: osoby starsze, przekład audiowizualny, dostępność mediów

\section{Introduction}

According to the Polish Central Statistical Office (GUS) (2020), in 2018, 76.5\% of Polish senior citizens - defined in this report as people aged 65 and above - declared that they never or almost never go to the cinema, $15.7 \%$ go 1-3 times a year and $7.6 \%$ go 2-3 times a month. The reasons for such a low interest in going to the cinema were not investigated in this study. However, from personal communication with senior citizens, we may discover that they might feel discouraged or even frightened by multiplexes because they are crowded and noisy, the air in screening rooms is too cold, other people from the audience eat during the film or the repertoire is at odds with senior citizens' interests. Other obstacles may include the price of the tickets and the proximity to the nearest cinema, as most of them are located in bigger cities. Finally, some senior citizens might prefer dubbing or voice-over (which is the main AVT method used on Polish television) because they find the subtitles too small and/or too fast to be able to read them comfortably.

In 2019, senior citizens in Poland accounted for $25.3 \%$ of the general population

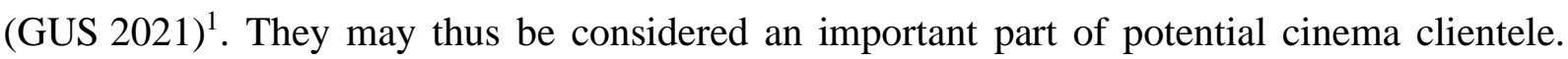
Unfortunately, little is known about this age group's specific preferences concerning audiovisual translation (AVT). Scholars have concentrated on younger audiences while research on senior citizens as recipients of audiovisual content has been scarce (Perego, del Missier \& Bottiroli 2015). Taking into consideration that normal aging might be associated with a number of impairments, it is reasonable to assume that it may influence senior citizens' needs related to AVT. Investigating these needs in greater detail may transfer into this age-group's better access to audiovisual material.

The aim of this article is to briefly discuss senior citizens as recipients of audiovisual translation: what choice of different AVT methods they currently have in Poland, what health issues pertaining to normal aging they might experience and what is the state of knowledge in the field of AVT and media accessibility concerning the needs, preferences and characteristics of this age-group. It is worth noting, however, that the minimum age of senior citizens has not

\footnotetext{
${ }^{1}$ In this publication, GUS defines older adults as people aged 60 and above.
} 
been precisely defined and it varies across publications. In reports published by GUS, for example, that age is either 60 - based on Polish law (GUS 2021) - or 65 and above - following the standards set by EUROSTAT (GUS 2017). That is why, to present a wider scope of available studies on the subject, this paper reports on the studies involving senior citizens aged both 60 and 65 and above.

\section{Audiovisual translation in Poland - an overview}

Audiovisual translation, once considered inferior to the translation of, for instance, literature, has gained a significant amount of attention from scholars over the last twenty years (Remael 2013). Such growth in the number of academic studies on the subject is understandable since an easy access to audiovisual content has dramatically increased and the media became a vital part of people's lives (Díaz-Cintas \& Anderman 2009). The arrival of digital television as well as online streaming platforms, such as Netflix, has marked a new era in the development of AVT modes, as preferences of the audience have been taken more into consideration (Ellis 2015). Apart from the "dominant types of AVT", as Gambier refers to them (2003: 172), namely: subtitling, dubbing and voice-over (VO), also access services, e.g. subtitling for the deaf and hard of hearing (SDH), audio description (AD) or audio subtitling (AST), received well-deserved recognition (Ellis 2015). This section provides a brief discussion of the most important modes of AVT and access services as well as their current status in Poland.

\subsection{Main modes of AVT}

The first type of AVT to be discussed is subtitling. According to Díaz-Cintas (2010: 344), "subtitling consists in rendering in writing the translation into a TL of the original dialogue exchanges uttered by the different speakers, as well as of all other verbal information that is transmitted visually (letters, banners, inserts) or aurally (lyrics, voices off)". This mode of AVT has proven to be the most popular one because its production is relatively fast and inexpensive, comparing to other known types of AVT (Díaz-Cintas 2013). However, as underlined by Gambier (2006), subtitlers often have to face a number of different constraints - both temporal and spatial.

One of the temporal constraints is the subtitle display time (Díaz-Cintas 2013). The socalled "six-second rule" suggests that a two-line subtitle, with a maximum of around 37 characters per line, should remain on the screen for six seconds in order to be read 
comfortably by viewers (Díaz-Cintas \& Remael 2007: 96). However, the shortest amount of time a subtitle is to be presented on the screen should be no less than one second to ensure that "the eye of the viewer can register its presence" (Díaz-Cintas 2010: 345). Another temporal constraint is the reading speed, which might be influenced, above all, "by the viewers' education, age, background, reading habits" as well as by the fact that they are watching a movie with subtitles in the cinema or on television (Gambier 2006: 259). Finally, temporal constraints also include the synchronisation of subtitles with the original soundtrack (PérezGonzález 2007). To achieve that, subtitlers must render their translations as concise as possible, as the average talking speed is often considerably faster than the audience's reading speed (Koolstra 2002). Spatial and visual constraints, in turn, oblige subtitlers to pay special attention to the acceptable number of lines and their positioning, shot changes as well as the number of characters or words per line (Gambier 2006). It is also worth mentioning that because of the nature of subtitles (the fact that viewers can always hear the original dialogue and compare it to the translation), they are often widely criticised, which may pose a serious challenge to subtitlers (Gambier 2006).

Over the years, one of the main arguments against subtitling was the assumption that it may be the cause of a more significant cognitive effort, compared to dubbing (Perego, Del Missier \& Marta Stragà 2018). Perego et al. (2018) suggest, however, that, as long as the subtitled film is not too complex, this translation mode does not significantly influence cognitive processing. They note, though, that a dubbed version might be a better choice for the "users who have reduced sensory and cognitive resources" as well as for those who are more used to this AVT mode (2018: 151). The advantages of subtitling, apart from relatively low production costs, include, for instance, the possibility to watch an AV material in a noisy environment or the fact that watching subtitled films enhances children's reading skills and facilitates foreign language learning (Koolstra 2002).

In Poland, until recently considered a voice-over country, the AVT trends appear to have shifted (Szarkowska \& Laskowska 2015). While on Polish television VO is the dominant AVT mode, some channels also introduce subtitling, thus giving their viewers a choice, and the majority of films in Polish cinemas are displayed with subtitles as well (Szarkowska \& Laskowska 2015).

Another major mode of AVT is dubbing. Chaume (2006: 6) defines it as an AVT method "consisting of a replacement of the original track of a film containing the source language dialogues for another track on which translated dialogues in the target language are recorded". One of the chief advantages of dubbing is the fact that the original soundtrack is replaced with 
a target language (TL) one and the audience is under the impression that the dialogue is produced in their mother tongue (Díaz-Cintas \& Orero 2013). As opposed to subtitling, the translation is provided through a spoken code, which makes it easy to follow, as the audience is not required to read while watching a film (Koolstra 2002). It is particularly important to those viewers who experience difficulties with reading or are illiterate (Ivarsson 1992). Moreover, because the original utterances are removed, the translator has more liberty to create a target language version that differs significantly from the source language (SL) one (Chaume 2006). That fact may be used to the translator's advantage e.g. while translating humorous passages or unfamiliar target culture (TC) elements as well as while synchronising the TL text with lip movements of the characters on the screen (Koolstra 2002). The lip-sync is expected to be as precise as possible; TL version should be adjusted to the length of the original utterances and even have similar distribution of vowels and consonants (Belczyk 2007).

However, in some cases the lack of the original soundtrack might also have negative consequences. The need for lip-synchronisation may sometimes result in some considerable changes being introduced into the original text or even the script (Ivarsson 1992). Moreover, dubbing might serve as a useful censorship tool since there is no way to compare the translation with the SL version (Koolstra 2002). Although it is worth noting that nowadays a growing number of online streaming platforms and even some televisions give their viewers an opportunity to switch between different AVT methods as well as watch content in the original version. Another drawback of dubbing is the fact that its production usually generates high costs, which might be rather discouraging (Díaz-Cintas \& Orero 2013). That is why, this translation mode is used mainly in some Western European countries, such as France, Spain or Germany (Szarkowska 2008). In addition, sometimes different films are dubbed by the same actors, which can be a disqualifying factor for some viewers as well (Koolstra 2002).

Dubbing in Poland, despite its long history, was less common mainly due to financial reasons. It was not until 2001 when an enormous success of the dubbed, largely domesticated version of Shrek sparked a revival of Polish dubbing (Leszczyńska \& Szarkowska 2018). Thus, in recent years, dubbing was generally associated with animated films. However, according to an article by natemat.pl, a Polish online magazine, this situation has begun to change, as cinemas in Poland have been offering increasingly more dubbed films for adult audiences (e.g. Deadpool 2). This mode of translation has gained many proponents in Poland who share their positive opinions online. Their main arguments in favour of dubbing include the possibility to immerse into the plot of the film better and to admire the artistry of Polish dubbing actors. Nevertheless, among Polish viewers dubbing also has a number of 
opponents who threaten to boycott new cinema productions if they are not distributed with subtitles (Godziński 2018).

Finally, the third most popular mode of AVT, after subtitling and dubbing, is voice-over. This method, as defined by Díaz-Cintas and Orero (2013), "consists in presenting orally a translation in a TL, which can be heard simultaneously over the SL voice" (p. 441). The SL dialogue is usually read by one person for every character on the screen; hence, the cost of voice-over is much lower than that of dubbing, which is one of its main advantages or, according to Belczyk (2007), its only advantage. Comparing to dubbing, VO is also much less complicated to produce since the dialogues do not have to be synchronised with lip movements (Díaz-Cintas \& Orero 2006). However, for those who are not accustomed to such a mode of translation, VO might sound odd and monotonous (Bogucki 2010). Additionally, scenes that include a number of characters speaking at the same time may cause confusion among viewers (Belczyk 2007; Bogucki 2010). That is why, in many countries, VO is used only for the translation of non-fictional genres (Díaz-Cintas \& Orero 2013).

In Poland, it is still common practice on Polish television to translate foreign productions with the use of voice-over (Bogucki 2010). The reason why it is that popular in Poland might be that the Poles are simply well acquainted with $\mathrm{VO}$ and it is rather inexpensive, comparing to the other AVT modes (Belczyk 2007). Additionally, many Polish viewers sometimes treat watching television as a secondary activity; they follow a film without looking at the screen and "the familiar voice of the lektor makes for a homely atmosphere" (Bogucki 2010: 6). However, according to the survey conducted by Szarkowska and Laskowska (2015), it might be reasonable to believe that Poland should no longer be viewed solely as a voice-over country. The vast majority of hearing respondents $(77 \%)$ selected subtitling as their preferred mode of AVT, although some of them noted that they might be inclined to choose VO if they are very tired or if watching television is not the only activity they are performing at a given moment. Hearing participants also underlined that they particularly enjoy watching films with subtitles if they know the language of the film because it gives them the opportunity to improve their skills. Additionally, the use of subtitling on Polish television would render it more accessible to the deaf and hard of hearing.

One might assume, though, that such a solution should be favoured by older adults, as according to a report by the Polish National Broadcasting Council (KRRiT 2011), 20 to 40 percent of television audience is over 60 years old and thus they may be the primary recipients of voice-over. That assumption seems to have been confirmed by a study carried out by Jankowska (2019) in which the participants over the age of 60 stated that if they were 
to choose any AVT mode in the cinema, they would be "likely" or "very likely" to select either voice-over $(96.5 \%)$ or dubbing $(96 \%)$. Thus, on the one hand, it is reasonable to assume that voice-over may soon be replaced by subtitling or dubbing (Belczyk 2007); on the other hand, each type of AVT caters for different needs of the viewers, who, especially in light of recent technological advances, should be able to choose the ones they prefer or the ones they are the most familiar with (Díaz-Cintas 1999; Koolstra 2002).

\subsection{Access services}

Subtitling for the deaf and hard of hearing, as defined by Künstler, is "a written version of the soundtrack of an audiovisual broadcast which includes the contents of utterances, such as dialogues, commentaries, as well as descriptions of any sounds that are necessary to understand the broadcast" (Künstler 2009: 115, my own translation). The main recipients who benefit from SDH are the deaf and hard of hearing, but it may also be useful to migrants who wish to improve their language skills (Gambier 2003) as well as to anyone who is not able to listen to the audio, for example, due to extensive noise (Künstler 2009).

It is important to mention that the group of the deaf and hard of hearing is heterogeneous. They differ, above all, with regard to the extent and type of deafness as well as reading skills they either have achieved a relatively high level of spoken language or they are in the process of learning it - which translates into different linguistic needs regarding subtitling (Künstler 2019). At the same time, they also express their preference for verbatim subtitles, which certainly exceed the acceptable reading speed rendering the AV material extremely difficult to follow (Szarkowska, Krejtz, Klyszejko, \& Wieczorek 2011). Künstler (2019) admits that at the moment the only solution that would be in line with both user preferences and academic findings would be to provide two versions of subtitles - verbatim and edited for viewers to choose from. However, in their eye-tracking study, Szarkowska et al. (2011) found that standard subtitles, which are edited but not simplified, are both acceptable and manageable for the deaf and hard of hearing. The choice between verbatim and edited subtitles, though, was not the only issue that has recently been researched. Szarkowska and Laskowska (2014) also studied user preferences regarding the kind of font, number of lines and subtitle layout. They conclude their research by stating that these preferences "may evolve over time and are inextricably linked with new technological developments" (2014: 196). Nevertheless, such studies gave rise to the first Polish guidelines regarding the creation of SDH prepared by Fundacja Kultury Bez Barier (Szczygielska 2019). 
In Poland, since 1994, SDH used to be provided solely by public television channel TVP1 (Künstler 2009); however, since the new legislation on media accessibility entered into force in 2018, all broadcasters have been obliged by the the Polish National Broadcasting Council (KRRiT) to provide access services for at least $25 \%$ of their quarterly broadcast time in 2020 and for at least 50\% in 2024 (Dz.U. 2018 poz. 915). Additionally, the KRRiT for the first time defined three types of subtitling (SDH, standard subtitling and live subtitling) and specified the minimum percentage of SDH (40\% of programmes) to be provided by broadcasters in 2024 (KRRiT 2018). Now, that user preferences have been described, guidelines have been created and new legislation has entered into force, Szczygielska (2019) points out that in the near future the quality of SDH needs to be effectively monitored and more SDH should be available in Polish cinemas.

According to Szarkowska and Jankowska (2015a: 191), audio description is "the technique which allows the blind and partially-sighted access to images, actions, settings, etc. thanks to descriptions inserted in gaps between the dialogues". Similarly to the deaf and hard of hearing, the group of the blind and partially-sighted is also heterogeneous, as some people lost their sight later in life and have some memory of watching audiovisual content, while others were born blind and thus they require a different level of detail (Gambier 2003). However, the blind and partially-sighted are not the only recipients of audio description; it might also be useful to those people who wish to watch their favourite programmes without having to look at the screen, e.g. while performing some other house activities, or for those who would like to record a programme and listen to it on the commute (Jankowska 2008). There are several scenarios in which the blind and partially-sighted might need $\mathrm{AD}$, for instance: in theatres or operas (where $\mathrm{AD}$ is usually provided in real time), while watching a program on television, in the cinema or on DVD (where AD is usually pre-recorded), in museums or galleries, during sports events (Matamala \& Orero 2013).

According to Jankowska (2018), the amount of AD on Polish television has been on the rise in recent years, although it still leaves much to be desired. That situation is very likely to change, however, as the above-mentioned legislation on media accessibility introduced in 2018 obliges broadcasters to provide audio description for at least $3.5 \%$ of their quarterly broadcast time in 2020 and for at least 7\% in 2024 (KRRiT 2018). In Polish cinemas, audio description, in the majority of cases, is provided during the screenings organised specifically for a group of the blind and partially-sighted, usually at a request of an NGO (Jankowska 2018). They are not regular, though, because Polish cinemas are reluctant to pay for a service that only a niche group of viewers would benefit from. That is why, the "AudioMovie - Cinema for All" project was 
launched to create a platform that would provide $\mathrm{AD}$ for the blind and partially-sighted independently, with the use of an application (Jankowska 2019).

Audio subtitling is understood as "aurally rendered and recorded version of subtitles with a film" (Reviers \& Remael 2015: 52). The primary recipients of AST are the blind and partiallysighted who, through the combination of AST with AD, are able to access foreign films (Jankowska 2019). Moreover, AST might also be useful for older adults and people with cognitive impairments (Braun \& Orero 2010). In some European countries, such as the Netherlands, audio subtitling is provided thanks to software that "converts the text into speech" (Braun \& Orero 2010: 173). In general, during a pilot study conducted by Braun and Orero (2010), such a method was well-received by viewers, but the quality of the synthetic voice is yet to be improved. Additionally, since AST is a spoken version of standard subtitling, there is a risk that the text that was primarily meant to be written might sound rather unnatural. Moreover, as subtitles are highly abbreviated and their complete understanding is closely linked with what is visible on the screen - for example, the identification of the speakers is not included in subtitles because they can be seen - the audio subtitles that are derived from them might be incomprehensible for the blind and partially-sighted. To avoid that problem, AST should always be accompanied by AD (Braun \& Orero 2010).

In Poland, owing to a long voice-over history, in order to make a foreign film fully accessible, $\mathrm{AD}$ can be combined with the already available voice-over translation (Szarkowska \& Jankowska 2015b) or AST, instead of being delivered with the use of synthetic voice, can be read out by a voice talent (Szarkowska \& Jankowska 2015a). According to a study carried out by Szarkowska and Jankowska (2015b: 245), it is important to the recipients of such a service that "AD does not overlap with the original actors' voices or with the voice-over translation" but, if it cannot be avoided, the AD can overlap only with the original dialogue. In addition, in order to avoid the problem with speaker identification, which is usually not included in the voice-over translation, the names of characters could be added to AD. Screenings of foreign films with both $\mathrm{AST}$ and $\mathrm{AD}$ for the blind and partially-sighted are rather rare. It is usually non-governmental organisations which are responsible for the organisation of such events because cinema industry does not consider them financially beneficial (Jankowska 2019). That is why, the AudioMovie application might be a viable solution for visually-impaired viewers to access foreign films (Jankowska 2019). Moreover, as suggested by a representative of the film industry, the application can also be used, for example, by senior citizens because they also might be seeking an alternative way of watching foreign cinema productions (Jankowska 2019). 


\section{Age-related sensorimotor and cognitive decline}

Age is one of the aspects that may presumably have a significant influence on film-watching as well as on the choice of a preferred AVT method. A survey conducted by Jankowska (2019) suggests that if senior citizens in Poland were to select a desired mode of translation in the cinema, the vast majority of them would be more inclined to choose dubbing or voice-over. It could be explained by the fact that, although the participants generally declared that subtitled films do not prevent them from going to the cinema, over a half of them reported having problems when reading the subtitles (Jankowska 2019). According to the study by Perego, del Missier \& Bottiroli (2015), comparing young adults and senior citizens who watched a subtitled and a dubbed version of a film, there is no significant difference between the two groups in terms of, above all, comprehension, information processing or enjoyment. The researchers admit, however, that senior citizens will always perform slightly worse than young adults due to the sensory and cognitive decline, which will be briefly discussed in this section.

\subsection{Sensorimotor decline}

Age-related hearing loss (ARHL) or "presbycusis refers to the physiological age-related changes of the peripheral and central auditory system leading to hearing impairment and difficulty understanding spoken language" (Roth, Hanebuth \& Probst 2011: 1101). It is one of the chief health concerns for senior citizens, as according WHO (2019a), it affects 30\% of the world's population over the age of 65 . Moreover, $80 \%$ of all people experiencing hearing loss are senior citizens (Gates \& Mills, 2005 in Roth et al. 2011).

It is difficult to establish what exactly causes ARHL, but some of the factors that influence its onset are aging, exposure to noise or genetic predispositions (Huang \& Tang 2010). According to Roth et al. (2011), the first physiological symptoms of ARHL typically include susceptibility to high frequency sounds. Thus, people affected by ARHL may experience problems with communication in a noisy environment (Huang \& Tang 2010). Hearing loss may also impact "the frequencies of the speech spectrum" (Roth et al., 2011: 1102). Then, a person with hearing impairment may lose the ability to recognise a sound and to identify its source (Huang \& Tang 2010). Further development of ARHL may obstruct the distinction between certain consonants, which, in turn, may have an adverse effect on communication, as people are able to hear speech, but they cannot understand it (Huang \& Tang 2010). Additionally, as highlighted by WHO (2013), it is characteristic of people with hearing impairments to speak more loudly without realising it and to experience "a ringing sensation in the ear". 
Such problems might have considerable influence on senior citizens' everyday lives (Van Eyken, Van Camp \& Van Laer 2007), in particular, on their social and cognitive functioning (Huang \& Tang 2010). Research by Kramer, Kapteyn, Kuik. \& Deeg (2002) found a significant correlation between hearing loss and social isolation, as the participants with ARHL displayed more symptoms of loneliness, depression and social exclusion, comparing to the participants without hearing impairments. Tun, McCoy and Wingfield (2009) also suggest that ARHL may be a cause of cognitive decline, as people with hearing loss may concentrate completely on identifying auditory information, thus, neglecting other cognitive activities. Additionally, Van Eyken et al. note that an elderly person affected by ARHL might also lose his or her sense of independence and suffer from anxiety.

In many cases, problems caused by ARHL may be solved with the use of hearing aids, owing to which difficulties with communication should effectively be avoided (Huang \& Tang, 2010). Unfortunately, people with ARHL very often refuse to admit to having a hearing impairment (McKenna \& Scott 2007). Moreover, in the UK, only around 30\% of people who have already been diagnosed with ARHL use a hearing aid (Huang \& Tang 2010).

Age-related visual impairment (ARVI) is also one of the most important health problems that elderly people experience, which may have a significant influence on their quality of life (Birren \& Williams 1982 in Wahl et al. 1999). According to the data provided by WHO (2019b), vision impairment and blindness affect more than 2 billion people, the majority of whom are senior citizens.

The main causes of ARVI are common eye diseases, such as macular degeneration, cataract or glaucoma (Zhang, Hua, Li, Tang, Sun \& Zhou 2008). Macular degeneration, for example, is increasingly more likely to occur after the age of 50 and may contribute to the development of legal blindness after the age of 65 (Jankowska-Lech, Grabska-Liberek, Krzyżewska-Niedziałek \& Pietruszyńska 2013). Other declines resulting from ARVI are linked with the process of aging itself and they include, above all: decline in the clarity of vision, reduced ability to differentiate between an object and its background, limited cooperation of the two eyes or decrease in the processing of visual information (Zhang et al. 2008) as well as "inaccuracy in visual-motor coordination" or "reduced depth judgement when walking and driving" (Loh \& Ogle 2004: 562). That is why, age-related vision impairment may considerably impact senior citizens' everyday lives (Loh \& Ogle 2004). Vision loss may be linked, for example, with higher frequency of such injuries as hip fracture (Wysong, Lee \& Sloan 2009). Individuals experiencing vision loss are also likely to display symptoms of depression caused mainly by social isolation (Bookwala \& Lawson 2011 in Casten \& Rovner 2013). 
Senior citizens may also experience a decline in manual function, "as reflected by the skilful use of the fingers in grasping, lifting, and manipulating objects" (Murata, Murata, Hiroshige, Ohtao, Horie \& Kai 2010: 180). It may be caused by a deterioration in sensation and muscular strength related to normal aging and can lead to problems in fulfilling everyday life activities (Shiffman 1992).

A study by Tremblay, Wong, Sanderson \& Coté (2003) suggested that the ability to use the tactile sense to detect different types of surfaces decreases with age. Such a decline in tactile spatial acuity may negatively influence senior citizens' performance of these activities that call for manual dexterity skills. According to the researchers, such changes might be attributed not only to aging, but also to various neuropathies that affect senior citizens. Another study by Murata et al (2010), which involved elderly females, investigated whether the age-related decrease in manual function coincides with the decline in tactile sensibility and muscular strength. The researchers measured manual dexterity, tactile-pressure threshold and handgrip strength. The results show that while tactile-pressure threshold changes with advancing age, handgrip strength appears to remain intact. Thus, it was concluded that "a well-maintained tactile sensation is more important for the manipulation of the hand in the elderly than muscular strength" (2010: 182). Finally, Carment et al. (2018) studied which activities involving manual function are influenced by normal aging and which are influenced by diagnosed cognitive decline. For that purpose, the researchers divided the participants into four groups: healthy senior citizens, senior citizens with diagnosed cognitive decline and two control groups of young and middle-aged adults. They found, for example, that tasks such as multi-finger tapping were more demanding for senior citizens with cognitive decline because they involved attention or working memory; whereas both groups of senior citizens had impaired independence of finger movements.

\subsection{Cognitive decline}

Although the decline of senior citizens' cognitive abilities may in some cases be caused by dementia, it is a part of the normal aging process (Harada, Natelson Lovec \& Triebeld 2013) and each person experiences it in his or her own individual way (Shaffer 2007). Researchers recognise two main kinds of cognition - crystallised and fluid (Salthouse 2012). Crystallised cognition concerns the knowledge that has already been acquired through life experiences; whereas fluid cognition refers to one's ability to solve new problems (Salthouse 2012). Crystallised cognitive abilities, such as vocabulary or general knowledge, are not affected by 
aging. Fluid cognitive abilities, however, tend to gradually deteriorate with age and they include, for example: processing speed, attention or memory (Harada et al. 2013).

Processing speed refers to "a rate at which people perform perceptual, motor and decisionmaking tasks" (Eckert, Keren, Roberts, Calhoun \& Harris 2010: 1). A review of 141 studies which used a Digit Symbol Substitution Test strongly indicates that advancing age may negatively influence processing speed of senior citizens (Hoyer, Stawski, Wasylyshyn \& Verhaeghen 2004). The decrease in processing speed may also be associated with sensory impairments as well as a general slowdown of the nervous system. That is why, senior citizens may not be able to fulfil complicated tasks, which can also affect their performance on the tests that measure their fluid cognitive abilities (Shaffer 2007). Additionally, a decrease in processing speed, alone or combined with sensory decline, may have a negative impact on senior citizens' memory (Frieske \& Park 1999).

A decline in attention demonstrated by senior citizens does not necessarily concern the ability to concentrate on one activity, but on several activities at once (Harada et al. 2013). Elderly people experience difficulties with selective and divided attention, that is, when they are to select only one piece of information or task to focus their attention on as well as when they are to perform several tasks at the same time (Harada et al. 2013). A study conducted by Connelly, Hasher \& Zacks (1991), for example, aimed at investigating how younger and older adults deal with distractions while reading. Their task was to read aloud texts with three kinds of distractions: meaningless, meaningful but irrelevant to the text and meaningful and relevant to the text. The distractions were highlighted in the text and the participants were to ignore them during reading. After comparing reading times of the two groups, the researchers found that senior citizens performed significantly worse than younger participants and it was especially difficult for them to ignore meaningful distractions that were relevant to the text.

Finally, aging also affects one's memory, that is, the general ability to recall something and the speed at which it can be done (Harada et al. 2013). Two types of memory may be subjected to age-related decline: episodic memory, which is related to one's experiences, and semantic memory, which concerns, for example, one's linguistic knowledge (Harada et al. 2013). As far as working memory is concerned, senior citizens, compared with younger adults, have more problems with deleting unimportant information from their working memory (Bowles \& Salthouse 2003). A plethora of information may, in turn, negatively influence the optimal working memory performance (Shaffer 2007). Moreover, senior citizens' capacity of working memory worsens once they perform two tasks simultaneously, for example, when they are asked 
to memorise a sequence of words and walk at the same time $(\mathrm{Li}$, Lindenberger, Freund \& Baltes 2001 in Shaffer 2007).

\section{Senior citizens as recipients of audiovisual content}

The previous section briefly outlined the sensorimotor and cognitive decline of senior citizens and how it may affect their everyday lives. Given that audiovisual content has become part of our daily activities, one may hypothesise that these age-related changes are also likely to influence senior citizens' film-watching experience, their preferences for specific modes of AVT or even their decision to spend their time on watching a film itself. This section describes the existing academic research in the field of AVT that deal with this age-group as well as some guidelines or projects that seek to find a way to ensure media accessibility for senior citizens.

\subsection{Senior citizens in AVT research}

There is little academic research concerning senior citizens' preferences of AVT modes. The survey by Jankowska (2019) - which involved 37 participants aged 60 and above - indicates that out of two AVT methods used in Polish cinemas, dubbing and subtitling, $93.55 \%$ of respondents would be likely or very likely to choose dubbing and $66.66 \%$ of them would be likely or very likely to choose subtitling. Additionally, $26.67 \%$ of respondents would be unlikely or very unlikely to choose subtitling. If the respondents could select from dubbing, subtitling and voice-over, $96 \%$ of them would be likely or very likely to choose dubbing, $96.55 \%$ of them would be likely or very likely to choose voice-over and $51.85 \%$ would be likely or very likely to choose subtitling, while $44.45 \%$ of them would be unlikely or very unlikely to choose subtitles.

The influence of intralingual subtitles on television-watching of senior citizens with hearing impairment was tested by Gordon-Salant and Callahan (2009). They found that when senior citizens are provided with subtitles, their understanding raises from $23 \%$ to $75 \%$ or to $81 \%$ if the elderly viewers use both subtitles and hearing aids. The researchers wondered, though, why subtitles and hearing aids did not ensure full understanding of the selected utterances. They hypothesised that the participants may not have had enough time to read the subtitles or that, given that "the televised picture contained varied and continuously changing visual images" (2009: 8), they found it difficult to concentrate on important information. However, the results of this study cannot be generalised, as it included a sample of only 15 participants and the stimuli 
in the form of several single sentences, although taken from real television programmes, were not provided with additional context.

A quasi-experimental study in the field of AVT with 67 senior citizens aged 60-78 as participants was also conducted by Perego, del Missier \& Bottiroli (2015). One of its objectives was to examine whether dubbing is rightly considered easier to process and more enjoyable to senior citizens, given their sensory and cognitive decay. To achieve that goal, the researchers carried out a case study in which older and younger adults (all native speakers of Italian) watched either a subtitled or dubbed 26-minute excerpt from the film Caramel by a Lebanese director Nadine Labaki (2007). After the viewing, the participants completed a test designed to measure their general comprehension, dialogue recognition, face-name association and visual scene recognition (tasks that require cognitive engagement) as well as a questionnaire measuring film appreciation, self-reported effort and judgements of memory. Having analysed the data, Perego et al. found no significant advantage of dubbing over subtitling. Instead, they found that differences between younger and older adults in cognitive task performance were related to agerelated cognitive decline, not to a translation mode. Moreover, older participants who watched the film with subtitles said that they did not invest more effort nor did they experience more difficulties pertaining to memory compared to the dubbing group. Senior citizens, however, enjoyed the subtitled viewing marginally more. The researchers admit, though, that future studies using more complex films as their stimuli might produce different results. It is worth noting that when Perego, Orrego-Carmona and Bottiroli (2016) enhanced the above-mentioned study by adding an excerpt of a more complex film, Sherlock, and by using eye-tracking, they found that the participants (only young adults this time) invested more effort into watching the subtitled version of a fast-paced film, despite stating otherwise in the questionnaire. However, due to the use of eye-tracking, the film excerpts used in the experiment were both shortened to 10 minutes. Perego et al. listed that as one of the limitations and pointed out that the duration of the stimuli is likely to affect the participants' reactions, as films in general tend to be significantly longer. Additionally, Perego et al. (2015) note that no translation method should be disregarded, as the deaf and hard-of-hearing and senior citizens with age-related hearing loss may prefer subtitling and children, illiterate people or senior citizens with vision impairment may benefit more from dubbing.

\subsection{Senior citizens and media accessibility}

As far as age-related sensory decline is concerned, a report Making Television Accessible (Looms 2011: 2) points out that "[t]hose over 65 are likely to suffer from two or more 
impairments", such as vision loss, hearing loss or deterioration of motor skills, which needs to be taken into consideration while designing accessible audiovisual services. Although the report does not provide specific guidelines aimed at visually-impaired senior citizens, it states that blind viewers who watch foreign productions can access them owing to audio subtitles (delivered in the UK, for example, with the use of speech synthesis). It is reasonable to assume that senior citizens with vision loss could also benefit from such a solution. Looms also indicates that senior citizens might find television programmes difficult to understand because of the obscure language characteristic of younger generations as well as fast-paced utterances. As suggested in the report, senior citizens might benefit from intralingual subtitles, pre-recorded or live, that use more condensed and simplified language. Subtitles might also prove useful for these viewers who experience age-related hearing loss.

In an attempt to address the needs of their audience, British Broadcasting Corporation (BBC) (2019) issued guidelines on how to make their audiovisual content more accessible. With the viewers with hearing loss in mind, they suggest that any key information that is provided orally should also be available in written form. The guidelines also state that people with hearing impairment may have difficulties with distinguishing background noise from the dialogue; thus, since increasing the volume is not a solution to this problem, film-makers are encouraged to avoid using background music if "the speaker has a strong accent, is softly spoken or may be difficult to understand for another reason" and anyone who appears on the screen is advised to speak clearly, to enunciate (at the end of sentences in particular) and to repeat important information. For the visually-impaired audience the $\mathrm{BBC}$ guidelines recommend that whenever possible essential written information should also be spoken. Furthermore, if a person on the screen speaks a foreign language, translation should be provided orally. However, BBC acknowledges that sometimes it is crucial to hear the original voice. In such cases, subtitles may be used but at least the gist of what has been said should be spoken at a later point in the broadcast, or the programme "should be considered for audio description". For any text that appears on the screen it is advised to use large, sans serif fonts as well as colours that contrast well with the images (the recommended colours are: green, yellow or white), although colours should be supported by the use of labels or icons to make the programme more accessible for people with colour blindness.

To the best of the author's knowledge, the first initiative that addressed the needs and preferences of senior citizens was the "AudioMovie - Cinema for All" project (Jankowska 2019). The project was initially carried out with the blind and partially-sighted in mind and sought to find a way that they could listen to alternative audio tracks while watching 
films in the cinema (which in Poland is dominated by subtitling). Thanks to the smartphone application called AudioMovie, the visually-impaired viewers can be provided with audio description as well as audio subtitles or dubbing during a screening. However, it was the cinema industry representatives who pointed out that the blind and partially-sighed constitute a rather niche target audience. In order for the application to be financially beneficial, the representatives suggested enlarging its user group e.g. by adding senior citizens who might be willing to use the application to watch foreign films with audio subtitling. That is why, the AudioMovie creators decided to conduct two studies - a usability test and a survey - to check senior citizens' interest in such a solution. So far, only the results of the latter have been reported. As mentioned above, the study indicates that respondents were more inclined to choose voice-over or dubbing than subtitling as their preferred mode of AVT. Moreover, 58.97\% of the participants reported having problems with reading subtitles, although they did not consider it a reason to avoid going to the cinema altogether. Finally, the researchers asked senior citizens if they would be willing to listen to the translation provided by a smartphone application while watching a film in the cinema. Almost a half of the responders (45\%) answered that they would be willing to use the application. At the same time, however, 55\% of the participants were either unwilling to use the app, or did not have an opinion. As the AudioMovie application was not introduced to the responders during this study, Jankowska concluded that only usability tests would be able to provide more reliable answer to that question. Finally, as highlighted by Jankowska, overall senior citizens are not proficient users of smartphones, which may be considered a significant drawback of the project.

\section{Conclusion}

Academic research on senior citizens' reception of audiovisual content and their preferences concerning AVT modes is scarce and incomplete. The available information suggests that senior citizens are a heterogenous group with specific needs regarding AVT and the cinema industry. One could assume that investigating these needs and addressing them might encourage this agegroup to consider cinema as a social activity that is worthy of their time and money. Senior citizens may experience both sensory decline, such as vision loss, hearing impairment and decay in manual function, and cognitive decline, concerning, for example, processing speed, attention and memory. Although more research in this field is needed to confirm it, it is reasonable to assume that these factors may influence their choice of a preferred AVT modality. Future studies may investigate, for example, whether senior citizens with vision loss and cognitive decline are 
more inclined to watch films with dubbing or voice-over and whether senior citizens with hearing loss prefer subtitles. They could also gather opinions of a representative sample of senior citizens on their preferences concerning AVT modes as well as the desired speed and size of subtitles. In order to fully understand senior citizens' process of film-watching, subsequent studies should pay attention to the genre and length of selected stimuli and involve such methods of data collection as eye-tracking. Finally, further research concerning this age-group, as proven by the AudioMovie project, may lead to an improvement of media accessibility not only for senior citizens, but also for other groups of viewers.

\section{References}

Belczyk, Arkadiusz (2007) Tłumaczenie filmów. Wilkowice: Wydawnictwo Dla Szkoły. Bogucki, Łukasz. (2010) "The Demise of Voice-Over? Audiovisual translation in Poland in the 21st century.” [In] Lewandowska-Tomaszczyk, Barbara, Thelen, Marcel (eds.) Meaning in translation. Lodz studies in language. Frankfurt am Main, Berlin, Bern, Bruxelles, New York, Oxford, Wien: Peter Lang, 1-10.

Bowles, Ryan P., Salthouse, Timothy A. (2003) "Assessing the Age-related Effects of Proactive Interference on Working Memory Tasks Using the Rasch Model.” Psychology and Aging. 18(3), 608-615. doi:10.1037/0882-7974.18.3.608.

Braun, Sabine, Orero, Pilar (2010). "Audio Description with Audio Subtitling - An emergent modality of audiovisual localisation." Perspectives: Studies in Translatology. 18(3), 173188. doi:10.1080/0907676X.2010.485687.

British Broadcasting Corporation (BBC) (2019) “Guidance: Visually Impaired and Hearing Impaired Audiences". Retrieved from https://www.bbc.com/editorialguidelines/guidance/visually-and-hearing-impairedaudiences\#1.

Carment, Loic, Abdellatif, Abir, Lafuente-Lafuente, Carmelo, Pariel, Sylvie, Maier, Marc A., Belmin, Joel, Lindberg, Pavel G. (2018) "Manual Dexterity and Aging: A pilot study disentangling sensorimotor from cognitive decline.” Frontiers in neurology. 9(910), 1-11. doi:10.3389/fneur.2018.00910.

Casten, Robin J., Rovner, Barry W. (2013) "Update on Depression and Age-related Macular Degeneration." Current Opinion in Ophthalmology. 24(3), 239-243. Retrieved from https://www.ncbi.nlm.nih.gov/pmc/articles/PMC5903583/pdf/nihms958290.pdf. 
Chaume, Frederic (2006) “Screen Translation: Dubbing.” [In] Brown, Keith (ed.)

Encyclopedia of language \& linguistics. Boston: Elsevier, 6-9.

Connelly, Lisa S., Hasher, Lynn, Zacks, Rose T. (1991) “Age and Reading: The impact of distraction." Psychology and Aging. 6(4), 533-541. doi:10.1037//0882-7974.6.4.533.

Díaz-Cintas, Jorge (1999) "Dubbing or Subtitling: The eternal dilemma." Perspectives. 7(1), 31-40. doi: .1080/0907676X.1999.9961346.

Díaz-Cintas, Jorge, Orero, Pilar (2006) “Voice-Over.” [In] Brown, K. (ed.), Encyclopedia of Language and Linguistics. Elsevier, 477-479

Díaz-Cintas, Jorge, Remael, Aline (2007) Audiovisual Translation: Subtitling. Manchester \& Kinderhook: St. Jerome.

Díaz-Cintas, Jorge, Anderman, Gunilla (2009) “Introduction.” [In] Díaz-Cintas, J., Anderman, G. (eds.), Audiovisual Translation: Language transfer on screen. Palgrave Macmillan UK., 1-17.

Díaz-Cintas, Jorge (2010) “Subtitling." [In] Gambier, Yves, van Doorslaer, Luc (eds.)

Handbook of Translation Studies. Amsterdam and Philadelphia: John Benjamins, 344349.

Díaz-Cintas, Jorge (2013) “Subtitling.” [In] Gambier, Yves., van Doorslaer, Luc (eds.),

Handbook of Translation Studies. Amsterdam/Philadelphia: John Benjamins Publishing Company, 344-349.

Díaz-Cintas, Jorge, Orero, Pilar (2013) "Voice-over and dubbing." [In] Gambier, Yves, van Doorslaer, Luc (eds.), Handbook of Translation Studies. Amsterdam/Philadelphia: John Benjamins Publishing Company, 441-445.

Eckert, Mark A., Keren, Noam I., Roberts, Donna R., Calhoun, Vince D., Harris, Kelly C. (2010) “Age-related Changes in Processing Speed: Unique contributions of cerebellar and prefrontal cortex." Frontiers in human neuroscience. 4(10). doi:10.3389/neuro.09.010.20.

Ellis, Katie (2015) "Netflix Closed Captions Offer an Accessible Model for the Streaming Video Industry, But What about Audio Description?.” Communication, Politics \& Culture Journal. 47(3), 1-20.

Frieske, David A., Park, Denise C. (1999) "Memory for News in Young and Old Adults." Psychology and Aging. 14(1), 90-98. doi: 10.1037//0882-7974.14.1.90.

Godziński, Bartosz (2018) "Predator po polsku, Borys Szyc jako Joker. Dubbing w kinach staje się normą i nie wszystkim się to (nie) podoba." natemat.pl. Retrieved from https://natemat.pl/239143,filmy-z-dubbingiem-dlaczego-w-kinach-jest-tak-duzo-polskichwersji. 
Gottlieb, Henrik (1998) “Subtitling.” [In] Baker, Mona \& Malmkjær, Kirsten (eds.), Routledge Encyclopedia of Translation Studies. London and New York: Routledge, 248-254.

Gambier, Yves (2003) "Introduction. Screen Transadaptation: Perception and reception." The Translator. 9(2), 171-189. doi: 10.1080/13556509.2003.10799152.

Gambier, Yves (2006) "Subtitling." [In] Brown, Keith (ed.), Encyclopedia of Language and Linguistics. Elsevier, 258-263.

Gordon-Salant, Sandra, Callahan, Julia S. (2009) "The Benefits of Hearing Aids and Closed Captioning for Television Viewing by Older Adults with Hearing Loss.” Ear Hear. 30(4), 458-465. doi: 10.1097/AUD.0b013e3181a26ef4.

Harada, Caroline N., Natelson Love, Marissa C., Triebeld , Kristen (2013) "Normal Cognitive Aging." Clinics in Geriatric Medicine. 29(4), 737-752. doi: 10.1016/j.cger.2013.07.002.

Hoyer, William J., Stawski, Robert S., Wasylyshyn, Christina, Verhaeghen, Paul (2004) "Adult Age and Digit Symbol Substitution Performance: A meta-analysis." Psychology and Aging,. 19(1), 211-214. doi: 10.1037/0882-7974.19.1.211.

Huang, Qi, Tang, Jianguo (2010) “Age-related Hearing Loss or Presbycusis.” European Archives of Oto-Rhino-Laryngology. 267, 1179-1191. doi: 10.1007/s00405-010-1270-7.

Ivarsson, Jan (1992) Subtitling for the Media: A handbook of an art. Transedit.

Jankowska, Anna (2008) “Audiodeskrypcja - szczytny cel tłumaczenia.” Między Oryginałem a Przekładem. 14, 225-246.

Jankowska, Anna (2018) "Patrząc w przeszłość, patrząc w przyszłość - 10 lat audiodeskrypcji filmowej w Polsce.' Między Oryginatem a Przekładem. 24(40), 139-158. doi: 10.12797/MOaP.24.2018.40.08.

Jankowska, Anna (2019) “Accessibility Mainstreaming and Beyond - Senior citizens as secondary users of audio subtitles in cinemas." International Journal of Language, Translation and Intercultural Communication. 28-47. doi:10.12681/ijltic.20275.

Jankowska-Lech, Irmina, Grabska-Liberek, Iwona, Krzyżewska-Niedziałek, Aldona, Pietruszyńska, Marta (2013) “Zwyrodnienie plamki związane z wiekiem (AMD) choroba starzejących się społeczeństw." Postępy Nauk Medycznych. 26(12), 868-873.

Kancelaria Sejmu (2018) Ustawa z dnia 22 marca 2018 r. o zmianie ustawy o radiofonii i telewizji. Retrieved from http://prawo.sejm.gov.pl/isap.nsf/DocDetails.xsp?id=WDU20180000915.

Krajowa Rada Radiofonii i Telewizji (2018) Rozporządzenie Krajowej Rady Radiofonii i Telewizji z dnia 15 listopada 2018 r. w sprawie udogodnień dla osób niepełnosprawnych z powodu dysfunkcji narządu wzroku i osób niepełnosprawnych z powodu dysfunkcji 
narządu słuchu w programach telewizyjnych. Retrieved from http://prawo.sejm.gov.pl/isap.nsf/DocDetails.xsp?id=WDU2018000226.

Kramer, Sophia E., Kapteyn, Theo S., Kuik, Dirk J., Deeg, Dorly J. (2002) “The Association of Hearing Impairment and Chronic Diseases with Psychosocial Health Status in Older Age." Journal of Aging and Health. 14(1), 122-137. doi: 10.1177/089826430201400107.

Künstler, Izabela (2009) "Napisy dla niesłyszących - problemy i wyzwania." Przektadaniec. 20, 115-124.

Künstler, Izabela, Butkiewicz, Urszula (2019) "Napisy dla osób niesłyszących i słabosłyszących - zasady tworzenia.” Fundacja Kultury bez Barier. Retrieved from http://napisy-audiodeskrypcja.pl/wp-content/uploads/2019/01/Napisy-dla-nieslyszacychzasady-tworzenia-NAPISY-AUDIODESKRYPCJA.pdf.

Koolstra, Cees M., Peeters, Allerd. L., Spinhof, Herman (2002) "The Pros and Cons of Dubbing and Subtitling." European Journal of Communication. 17(3), 325-354. doi: $10.1177 / 0267323102017003694$.

Leszczyńska, Urszula, Szarkowska, Agnieszka (2018) “'I Don’t Understand, But it Makes me Laugh'. Domestication in contemporary Polish dubbing." Journal of Specialised Translation. 30, 203-231.

Lin, Frank R., Thorpe, Roland, Gordon-Salant, Sandra, Ferrucci, Luigi (2011). "Hearing Loss Prevalence and Risk Factors among Older Adults in the United States.” The Journals of Gerontology: Series A. 66A(5), 582-590. doi: 10.1093/gerona/glr002.

Loh, Keng Yin, Ogle, J. (2004) "Age related visual impairment in the elderly." Med J Malaysia. 59(4), 562-568.

Looms, Peter Olaf (2011). "Making Television Accessible.” Retrieved from: https://www.itu.int/en/ITU-D/Digital-Inclusion/Persons-withDisabilities/Documents/Making_TV_Accessible-English.pdf.

Malinowska, Anna (2012) "Seniorzy nie chodzą do kina, bo filmy drogie, sale zimne i pachnie chrupkami." Gazeta Wyborcza. Retrieved from https://wyborcza.pl/1,75248,11867884,Seniorzy_nie_chodza_do_kina_bo_filmy_drogie sale.html.

Matamala, Anna, Orero, Pilar (2013) “Standardising Audio Description.” Italian Journal of Specialised Education for Inclusion. 1(1), 149-155.

McKenna, Laurence, Scott, David (2007) “Acquired Hearing Loss.” [In] Ayers, Susan, Baum, Andrew, McManus, Chris, Newman, Stanton, Wallston, Kenneth, Weinman, John, West, 
Robert (eds.). Cambridge Handbook of Psychology, Health and Medicine. Cambridge: Cambridge University Press, 665-667. doi:10.1017/CBO9780511543579.157.

Murata, Jun, Murata, Shin, Hiroshige, Jiro, Ohtao, Hiroshi, Horie, Jun, Kai, Yoshihiro (2010) "The Influence of Age-related Changes in Tactile Sensibility and Muscular Strength on Hand Function in Older Adult Females.” International Journal of Gerontology. 4(4), 180183. doi: 10.1016/j.ijge.2010.11.004.

Perego, Elisa, Del Missier, Fabio, Bottiroli, Sara (2015) "Dubbing Versus Subtitling in Young and Older Adults: Cognitive and evaluative aspects." Perspectives. 23(1), 1-21. doi: 10.1080/0907676X.2014.912343.

Perego, Elisa, Orrego-Carmona, David, Bottiroli, Sara (2016) “An Empirical Take on the Dubbing vs. Subtitling Debate: An eye movement study." Lingue e Linguaggi. 19, 255274. doi: $10.1285 / 122390359 v 19 p 255$.

Perego, Elisa, Del Missier, Fabio, Stragà, Marta (2018) "Dubbing vs. Subtitling. Complexity matters." Target. 30(1), 137-157. doi: 10.1075/target.16083.per.

Pérez-González, L. (2007) "Intervention in New Amateur Subtitling Cultures: A multimodal account." Linguistica Antverpiensia, New Series - Themes in Translation Studies. 6, 6780. Retrieved from http://luisperezgonzalez.org/wpcontent/uploads/2020/08/LANS6 LP final journal copy.pdf.

Remael, Aline (2013) “Audiovisual Translation.” [In] Gambier, Yves, van Doorslaer, Luc (eds.), Handbook of Translation Studies. Amsterdam/Philadelphia: John Benjamins Publishing Company, 12-17.

Reviers, Nina, Remael, Aline (2015) "Recreating Multimodal Cohesion in Audio Description: A case study of audio subtitling in Dutch multilingual films." New Voices in Translation Studies. 13, 50-78.

Roth, Thomas Niklaus, Hanebuth, Dirk, Probst, Rudolf (2011) "Prevalence of Age-related Hearing Loss in Europe: A review." European Archives of Oto-Rhino-Laryngology. 268(8), 1101- 1107 doi: 10.1007/s00405-011-1597-8.

Salthouse, Timothy (2012) "Consequences of Age-related Cognitive Declines." Annual Review of Psychology. 63, 201-26. doi: 10.1146/annurev-psych-120710-100328. Shaffer, David W. (2007) “Age and Cognitive Functioning.” [In] Ayers, Susan, Baum, Andrew, McManus, Chris, Newman, Stanton, Wallston, Kenneth, Weinman, John, West, Robert (eds.) Cambridge Handbook of Psychology, Health and Medicine. Cambridge: Cambridge University Press, 15-20. doi: 10.1017/CBO9780511543579.004. 
Shiffman, Lori M. (1992) "Effects of Aging on Adult Hand Function." American Journal of Occupational Therapy. 46, 785-792. doi: 10.5014/ajot.46.9.785.

Szarkowska, Agniieszka (2009) "Przekład audiowizualny w Polsce - perspektywy i wyzwania." Przekładaniec. 20, 8-25.

Szarkowska, Agnieszka, Krejtz, Izabela, Klyszejko, Zuzanna, Wieczorek, Anna (2011)

Verbatim, Standard, or Edited? Reading patterns of different captioning styles among deaf, hard of hearing, and hearing viewers." American Annals of the Deaf. 156(4), 363378. doi:10.1353/aad.2011.0039.

Szarkowska, Agnieszka, Laskowska, Monika (2015) "Poland - A Voice-over Country no More? A report on an online survey on subtitling preferences among Polish hearing and hearing-impaired viewers.” [In] Bogucki, Łukasz, Deckert, Mikołaj (Eds.). Accessing audiovisual translation. Bern: Peter Lang, 179-197.

Szarkowska, Agnieszka, Jankowska, Anna (2015a) “Audio Subtitling Multilingual Films in Poland: Early developments, current practices and future challenges." [In] Szarkowska, Agnieszka, Jankowska, Anna (eds.) New Points of View on Audiovisual Translation and Media Accessibility. Oxford, Bern, Berlin, Bruxelles, Frankfurt am Main, New York, Wien: Peter Lang, 191-216. doi: https://doi.org/10.3726/978-3-0353-0761-0.

Szarkowska, Agnieszka, Jankowska, Anna (2015b) “Audio Describing Foreign Films.” Journal of Specialised Translation. 23, 243-269.

Szczygielska, Monika (2019) "Napisy dla niesłyszących w Polsce. Historia, problemy, wyzwania.” Pótrocznik Językoznawczy Tertium. Tertium Linguistic Journal. 4(1), 193210. doi: 10.7592/Tertium2019.4.1.Szczygielska.

The Polish Central Statistical Office (2017) “Jakość życia osób starszych w Polsce”. Retrieved from https://stat.gov.pl/obszary-tematyczne/warunki-zycia/dochody-wydatki-iwarunkizycia-ludnosci/jakosc-zycia-osob-starszych-w-polsce, 26,1.html.

The Polish Central Statistical Office (2020) “Jakość życia osób starszych w Polsce”. Retrieved from https://stat.gov.pl/obszary-tematyczne/warunki-zycia/dochody-wydatki-i-warunkizycia-ludnosci/jakosc-zycia-osob-starszych-w-polsce, 26,2.html.

The Polish Central Statistical Office (2021) "Sytuacja osób starszych w Polsce w 2019 r." Retrieved from https://stat.gov.pl/obszary-tematyczne/osoby-starsze/osobystarsze/sytuacja-osob-starszych-w-polsce-w-2019-roku,2,2.html.

Tremblay, François, Wong, Kim, Sanderson, Robin, Coté, Leanne (2003) “Tactile Spatial Acuity in Elderly Persons: Assessment with grating domes and relationship with manual 
dexterity." Somatosensory \& Motor Research. 20(2), 127-132. doi: $\underline{10.1080 / 0899022031000105154 .}$.

Tun, Patricia A., McCoy, Sandra, Wingfield, Arthur (2009) “Aging, Hearing Acuity, and the Attentional Costs of Effortful Listening." Psychology and Aging. 24(3), 761-766. doi: $10.1037 / \mathrm{a} 0014802$.

Van Eyken, E., Van Camp, G., Van Laer, L. (2007) “The Complexity of Age-related Hearing Impairment: Contributing environmental and genetic factors." Audiology and Neurotology. 12(6), 345-358. doi: 10.1159/000106478.

Wahl, Hans-Werner, Schilling, Oliver, Oswald, Frank, Heyl, Vera (1999) "Psychosocial Consequences of Age-related Visual Impairment: Comparison with mobility-impaired older adults and long-term outcome." Journal of Gerontology: PSYCHOLOGICAL SCIENCES. 54b(5), 304-316. doi:10.1093/geronb/54b.5.p304.

World Health Organisation. (2013, February) “Age-related hearing loss (presbycusis).” https://www.who.int/features/qa/83/en/.

World Health Organisation. (2019a, March, 22) "Deafness and hearing loss." https://www.who.int/news-room/fact-sheets/detail/deafness-and-hearing-loss.

World Health Organisation. (2019b, October, 8) "Blindness and vision impairment." https://www.who.int/news-room/fact-sheets/detail/blindness-and-visual-impairment. Wysong, Ashley, Lee, Paul P, Sloan, Frank A (2009) "Longitudinal Incidence of Adverse Outcomes of Age-related Macular Degeneration." Archives of Ophthalmology. 127, 320327. doi:10.1001/archophthalmol.2008.613.

Zhang, Changzheng, Hua, Tianmiao, Li, Guzhou, Tang, Chuanhong, Sun, Qingyan, Zhou, Peiling (2008) "Visual Function Declines During Normal Aging." Current Science. 95(11), 1544-1550. 